\title{
AN INTEGRATED BIO-HYDROTHERMAL CONVERSION OF IRON-HYDROXY-SULFATES INTO HEMATITE: ENDEAVOUR TO 4R'S
}

\author{
SRADHANJALI SINGH ${ }^{1}$, MALAY KUMAR GHOSE ${ }^{2}$, \\ LALA BIHARI SUKLA ${ }^{3}$ \& SANJEEV KUMAR GOYAL ${ }^{1}$ \\ ${ }^{1}$ CSIR-National Environmental and Engineering Research Institute, India \\ ${ }^{2}$ CSIR-Institute Of Minerals and Materials Technology, India \\ ${ }^{3}$ Biofuels And Bioprocessing Research Center, Siksha 'O' Anusandhan University, India
}

\begin{abstract}
Iron being a common impurity in hydrometallurgical operations; create significant difficulties during the recovery of other bivalent base metals. High content of iron in the form of oxides and metals in these processes could be solved by producing iron oxide pigments, which can be successfully converted into valuable raw material for paint, cosmetic, pharmaceutical, dye, and chemical industries. Furthermore, it could easily and economically generate additional revenue to develop the infrastructural facilities, the operation and maintenance costs required for full functional operational plant and certainly add value to the economy of these sectors. In above context, an attempt was made to convert the iron-hydroxy-sulfates formed in the leachate of the tailing pond of iron ore mine, Odisha into hematite. The process flow sheet encompasses biological followed by hydrothermal route to attain $100 \%$ pure hematite. Prior to hydrothermal conversion, complete ferrous oxidation was ensured in a $2.5 \mathrm{~L}$ of stirred tank batch bioreactor. Precipitates were generated at room temperature by the addition of either a concentrated $\mathrm{NaOH} / \mathrm{Ca}(\mathrm{OH})^{2}$ until the $\mathrm{pH}$ attained the desired value. The ferric rich slurry thereafter converted to hematite in a $2.5 \mathrm{Lit}$ of SS grade high pressure vessel reactor (Stainless Steel grade 316) for $5 \mathrm{hrs}$ at $400 \mathrm{rpm}, 180^{\circ} \mathrm{C}, 1.34 \mathrm{MPa}$. The XRD pattern shows only the presence of iron oxide $\left(\mathrm{Fe}_{2} \mathrm{O}_{3}\right)$ (PANalytical Empyrean Series 2\X'pert high score: -98-017-3654) which was well validate by SEM-EDX analysis for elemental identification and quantitative compositional information (CARL ZEISS, model-EVO18). Particle size analysis were also carried out using Malvern hydro mastersizer (model: 2000M) and UV-DRS analysis.
\end{abstract}

Keywords: iron ore mine, tailing pond, bio-hydrothermal conversion, commercial, viable, hematite.

\section{INTRODUCTION}

To meet the growing demand for metals and related products, the metals and mining industries started processing the secondary resources which consequently generate huge amount of wastes such as low grade ores, overburdens, fines/tailings. Such wastes often become concern for any mineral processing industry due to environmental issues that are associated with it. The concept of utilization of solid wastes embraces three basic principles of recovery, recycling and converting to high value added products.

India is endowed with great mineral wealth. Properly tapped, it can help to propel India's GDP growth [1]. Mining also provides the growth of India's mineral based districts which are considered to be the poorest states. Nevertheless, mining sector's growth is equally crucial for India's growth in next decade. About 90 percent of all mining is done by surface mining, which is much cheaper than underground mining. The Opencast mining methods are therefore more pollution intensive as they generate 8 to 10 times more quantities of waste compared to the underground mines. Waste rock, tailings and other solid waste are the largest industrial solid waste generated in the process of exploitation of mineral resources. This requires more land for their storage.

Tailings are the major solid wastes produced in the process of mineral beneficiation that are usually transported in slurry form to a disposal facility, where the solid particles are 
allowed to settle down and the leachates get collected in secondary tailing ponds. However, these ponds are overloaded with high concentration of iron, $\mathrm{SO}_{4}{ }^{2-}$ ions along with base transition metals, such as iron, copper, nickel and zinc, in relatively high concentrations. They occasionally also contain precious metals such as gold and silver, in minerals (and native metals) that have been not been alienated by froth flotation. Therefore, it will be worthwhile to say these tailing ponds could otherwise serve as a potential source for extraction of base metals and would certainly cope with the extraction cost in compare to the cost required for mining deep-buried primary ore bodies. One of the best examples is Kasese copper mine in Uganda, where Co was recovered through bioleaching process from the cobalt rich tailings the closure of the mine site [2], [3].

Secondly, looking to the market price for minerals and metals, it provides a substitute to pull out metals from mine waste streams especially from tailing ponds. Nowadays with the advancement in the mineral processing and separation technologies, it becomes possible to recover back the usable forms of metals/minerals from the tailings ponds and recycle the treated water for other purpose. This brings up the axiom of 3R's (Reuse, Reduce and Recycle), all the stakeholders that includes government, mining industries and private sectors should come together for the exploration, extraction and recovery of the untapped wealth so far remain intact beneath the soil.

Whether it is sulphidic or oxidic mineral, Fe remains inherent. Therefore, it always interferes during beneficiation process. The intricacy remains in its separation and subsequent removal from other base metals. The paper aims to recover high grade $\mathrm{Fe}_{2} \mathrm{O}_{3}$ (pure red iron oxide) from iron ore tailing ponds and sell it as a raw material in other line productions whereby the mining industry can offset the processing cost. After successful trials in laboratory scale, a conceptual flow diagram and equipment process sheet have been developed for treating the iron ore tailing ponds. Nonetheless, the process can not only be applied for treatment of Acid Mine Drainage problem but also treating the leach liquors generated during hydrometallurgical and electro winning processes.

\section{METHODOLOGY}

\subsection{Equipment and chemicals}

All chemicals used in this study were analytical grade reagents and were prepared with distilled water. Samples taken for ICP analysis were filtered through a $0.45 \mu \mathrm{m}$ disposable membrane filters to remove cells and residual particles. The glass $\mathrm{pH}$ probe and meter (Thermo Electron Corporation USA, model Orion 4 Star) was calibrated with $\mathrm{pH} 1.68, \mathrm{pH}$ 4 , and $\mathrm{pH} 7$ buffers following the manufacture's procedures. Culture medium potential was measured with relative to an $\mathrm{Ag} / \mathrm{AgCl}_{(1 \mathrm{M} \mathrm{KCl})}$ reference electrode fitted to a digital meter (Thermo Electron Corporation USA, model 720A+).

\subsection{Bacteria culture and media preparation}

An iron-oxidizing bacterium namely Acidithiobacillus ferrooxidans (At. ferrooxidans) was used for the biological conversion of ferrous ions into ferric ions. The bacterial culture was procured from Japan Culture Type Collection Centre (JCM, RIKEN, Japan) and maintained by sub-culturing into fresh IEM growth medium containing ferrous sulfate hepta hydrate as a substrate. 


\subsubsection{Preparation and composition of the IEM medium}

The IEM composition consists of three parts: Solution A was a solution of $\mathrm{FeSO}_{4} \cdot 7 \mathrm{H}_{2} \mathrm{O}$ dissolved in concentrated $\mathrm{H}_{2} \mathrm{SO}_{4}$ and the volume was made up to $1 \mathrm{~L}$ by deionised water, $\mathrm{pH}$ of $1.50 \pm 0.05$. Solution $\mathrm{B}$, a macro-nutrient solution was prepared from the following salts: $\left(\mathrm{NH}_{4}\right)_{2} \mathrm{SO}_{4}(5.00 \mathrm{~g}), \mathrm{K}_{2} \mathrm{HPO}_{4}(2.50 \mathrm{~g}), \mathrm{MgSO}_{4} \cdot 7 \mathrm{H}_{2} \mathrm{O}(2.50 \mathrm{~g})$ andCaCl${ }_{2} \bullet 0.5 \mathrm{H}_{2} \mathrm{O}(0.100 \mathrm{~g})$ dissolved in $1.00 \mathrm{~L}$ of deionised water. Solution $\mathrm{C}$, a solution of micro-nutrients was prepared from the following salts: $\mathrm{CoSO}_{4} \cdot 7 \mathrm{H}_{2} \mathrm{O}(2.49 \mathrm{~g}), \mathrm{CuSO}_{4} \cdot 7 \mathrm{H}_{2} \mathrm{O}(2.81 \mathrm{~g}), \mathrm{MnSO}_{4} \bullet \mathrm{H}_{2} \mathrm{O}(1.69$ g), $\left(\mathrm{NH}_{4}\right)_{6} \mathrm{Mo}_{7} \mathrm{O}_{24} \bullet 4 \mathrm{H}_{2} \mathrm{O}(1.77 \mathrm{~g}), \mathrm{NiSO}_{4} \bullet 6 \mathrm{H}_{2} \mathrm{O}(2.62 \mathrm{~g})$ and $\mathrm{ZnSO}_{4} \bullet 7 \mathrm{H}_{2} \mathrm{O}(2.87 \mathrm{~g})$ dissolved in $1.00 \mathrm{~L}$ of deionised water. The final medium was prepared by mixing the three parts and adjusting the final $\mathrm{pH}$ to $1.50 \pm 0.05$ with concentrated $\mathrm{H}_{2} \mathrm{SO}_{4}$ [4]. Cultures were incubated at $35 \pm 2^{\circ} \mathrm{C}$, in a vessel fitted with an air sparge and a mechanical overhead stirrer at a flow rate of $1 \mathrm{~L} / \mathrm{min}, 150 \mathrm{rpm}$. Cells were harvested by filtration through a Whatman \#1 paper followed by collecting on a $0.45 \mu \mathrm{m}$ membrane filter and re-suspended in a fresh medium.

\subsection{Mineralogical and chemical characterization of iron ore tailings}

The fine-grained residues called the tailings are deposited near the mine and pumped together with the process water to large ponds, known as tailings impoundments, where it gets settled and deposited. These fine residues were collected, dried and disaggregated to obtained a sieve fraction of $\leq 75 \mathrm{microns}$. The elemental compositions of selected elements were determined by inductively coupled plasma-optical emission spectroscopy (ICR-OES) whereas the mineralogy of the tailing sample was determined by X-ray diffraction (XRD). Results showed the presence of major iron $(\mathrm{Fe})$ bearing phase Ferrihydrite $\left(\mathrm{Fe}^{3+}{ }_{2} \mathrm{O}_{3} \bullet 0.5\left(\mathrm{H}_{2} \mathrm{O}\right)\right.$ a hexagonal-close-packed layers of $\mathrm{O}_{2}, \mathrm{OH}$, and $\mathrm{H}_{2} \mathrm{O}$ with $\mathrm{Fe}(\mathrm{III})$ occupying in the octahedral positions, hematite $\left(\mathrm{Fe}_{2} \mathrm{O}_{3}\right)$, quartz and gangue minerals such as alumina and silica were present in the form of kaolinite $\left[\mathrm{Al}_{2} \mathrm{Si}_{2} \mathrm{O}_{5}(\mathrm{OH})_{4}\right]$ and Gibbsite $\left(\mathrm{Al}(\mathrm{OH})_{3}\right)$ (Fig. 2). The chemical analysis of the tailing is presented in Table 1 .

\subsection{Bioconversion of tailing effluent by At. ferrooxidans}

Bench-scale batch experiment was performed in a $2.5 \mathrm{~L}$ baffled glass reactor. $900 \mathrm{~mL}$ of tailing effluent (after passing through whatmann\#1) was added to $500 \mathrm{~mL}$ of iron free IEM media inoculated with $100 \mathrm{ml}$ bacterial suspension (At. ferrooxidans). The total working volume of the glass reactor kept was $1.5 \mathrm{~L}$. Homogenous mixing was achieved by using a propeller stirrer at a rotation of $150 \mathrm{rpm}$. A temperature of $35^{\circ} \mathrm{C}$ inside the bioreactor was maintained by placing a hot plate beneath the reactor. Water loss due to evaporation was compensated by addition of deionized water on a regular basis. To maintain the oxygen level,
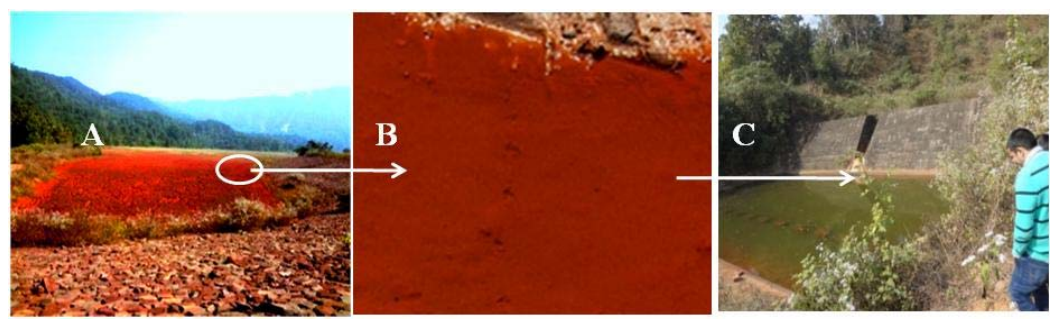

Figure 1: Photograph showing: (a) Overview of a tailing pond; (b) Close view of tailing effluent; (c) Clarification impoundment pond (after settling in the impoundment pond the excess water gets accumulated in this pond). 


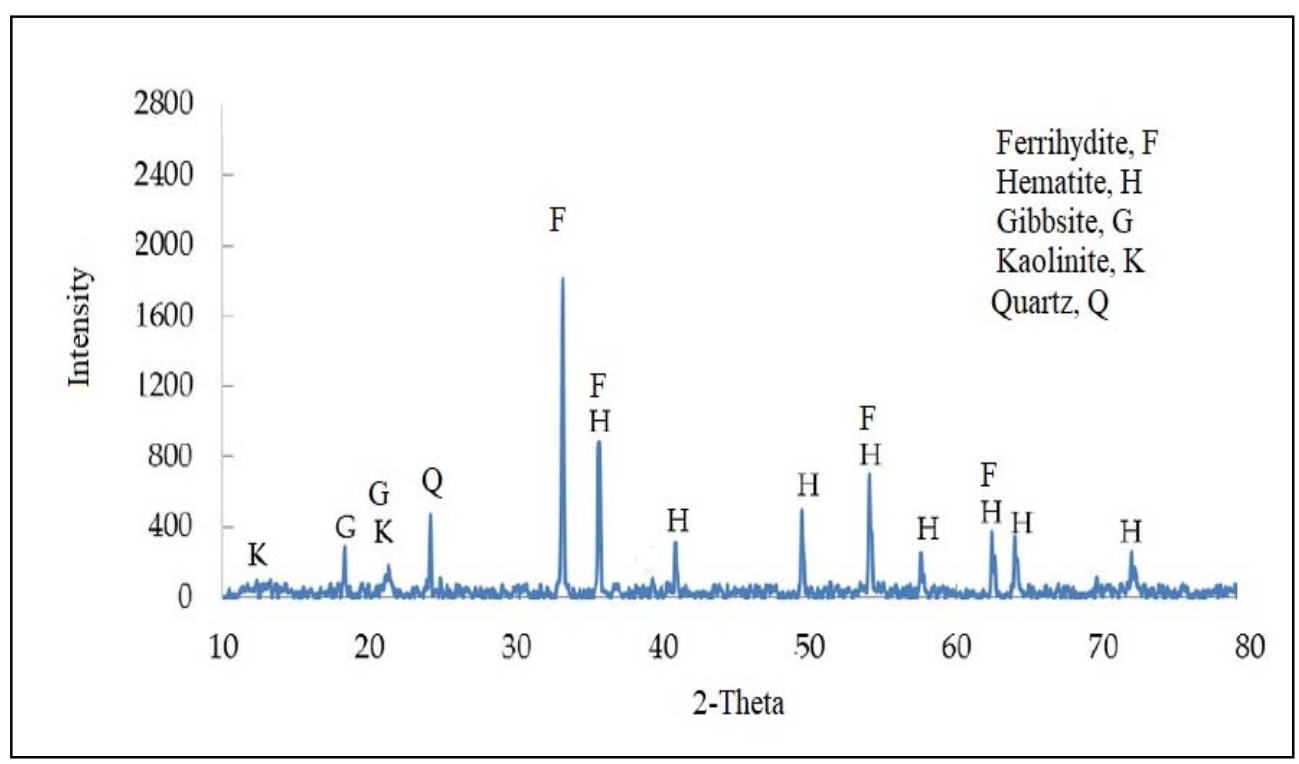

Figure 2: XRD pattern of tailing fine residues after drying.

Table 1: Elemental analysis of tailing effluent.

\begin{tabular}{lc}
\hline Elements & $(\mathrm{mg} / \mathrm{L})$ \\
\hline Iron & $1-4$ \\
Magnesium & 0.34 \\
Nickel & 0.001 \\
Chromium & 0.003 \\
Cobalt & 0.001 \\
Zinc & 0.005 \\
\hline
\end{tabular}

air was blown at a flow rate of $1 \mathrm{~L} / \mathrm{min}$ underneath the propeller. Regular monitoring of $\mathrm{Fe}^{2+}$ and $\mathrm{Fe}^{3+}$ concentrations, $\mathrm{pH}$, and redox potential was recorded until complete conversion of ferrous to ferric ions was achieved and the whole content was transferred to a $5 \mathrm{~L}$ of glass beaker for further processing.

\subsection{Precipitate generation}

The solution was allowed to precipitate at room temperature in a $5 \mathrm{~L}$ beaker, fitted with a magnetic stirrer, by addition of either a concentrated $>5 \mathrm{M}$ solution of $\mathrm{NaOH}$ or a saturated solution of $\mathrm{Ca}(\mathrm{OH})_{2}$ until the $\mathrm{pH}$ attained the desired value, $>\mathrm{pH} 3.4$. The precipitate was allowed to settle for 24 hours before decanting the supernatant. Hydrolysis of the soluble iron by addition of alkali $\left[\mathrm{NaOH} / \mathrm{Ca}(\mathrm{OH})_{2}\right]$ to precipitate the metal as ferric hydroxide at $\mathrm{pH}$ 3.6. This allows the separation of iron from other metals present in the sludge followed by successive washing with an aqueous solution at the same $\mathrm{pH}$ to remove the undesirable contaminants as shown in eqn (1): 


$$
\mathrm{Fe}^{3+}(\mathrm{aq})+3 \mathrm{OH}^{-}(\mathrm{aq}) \rightarrow \mathrm{Fe}(\mathrm{OH})_{3}(\mathrm{~s}) .
$$

\subsection{Pressure vessel operating conditions and hydrothermal conversion}

Conversion of the Fe slurry to hematite was performed in a $2.5 \mathrm{~L}$ of SS grade (stainless steel) high-pressure reactor vessel (design for 100 bar g pressure) (Fig. 3). The operation parameters were set via SS control panel with programmable P.I.D temperature controller and the speed controller. Vessel operating conditions for the precipitate conversion into hematite were $200^{\circ} \mathrm{C}$, pressures $1.34 \mathrm{MPa}$, and $200 \mathrm{rpm}$ stirrer rotation speed. The temperature was ramped over a $1 \mathrm{hr}$ to $200^{\circ} \mathrm{C}$ then held at that temperature for 5 hours. Samples were withdrawn after the reaction period was over and solid/liquid separation was done by filtration technique. The supernatant was collected in separate bottles and residues were subjected to three successive washings. The initial and final weight of the filter was weighed and residue was allowed to dry at $50^{\circ} \mathrm{C}$ overnight. The final product obtained was analyzed by XRD, SEM, FT-IR to ensure the purity.

\subsection{Characterization of final product (hematite)}

\subsubsection{XRD analysis}

Iron oxide $\left(\alpha-\mathrm{Fe}_{2} \mathrm{O}_{3}\right)$ obtained was characterized by using PANalytical X'Pert PRO MRD Xray diffractometer powered by a Philips PW3040/60 X-ray generator and fitted with an $\mathrm{X}^{\prime}$ Celerator* detector. Diffraction data acquired by exposing powder samples to $\mathrm{Cu}-\mathrm{K} \alpha \mathrm{X}$ ray radiation, which has a characteristic wavelength $(\lambda)$ of $1.5418 \AA$. X-rays were generated from a $\mathrm{Cu}$ anode supplied with $40 \mathrm{kV}$ and a current of $40 \mathrm{~mA}$. Samples were disaggregated with an agate pestle and mortar, and were mounted into the holders and placed in the diffractometer. XRD patterns were collected in an angular range of $2 \Theta$ from $10^{\circ}$ to $90^{\circ}$. Phase identification was carried out by means of the X'Pert accompanying software program PANalytical High Score.

\subsubsection{SEM-EDX and FT-IR analysis}

Scanning electron microscope study was carried out by using the Scanning Electron Microscope (SEM) and Energy Dispersive X-Ray (EVO 18 SEM from Carl Zeiss, Germany) fitted with BDS detector, $50 \mathrm{~nm}$ secondary e-image resolution, EHT-30 KV to $200 \mathrm{~V}$ with a

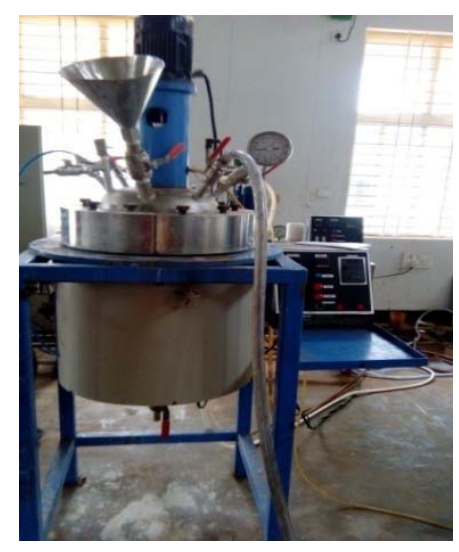

Figure 3: High pressure reactor vessel for hydrothermal conversion. 
magnification limit ranging from $50 \mathrm{~K}-100 \mathrm{~K}$. The Fourier transform infrared (FTIR) spectra was recorded on a Nicolet Impact 6700(Thermo scientific) infrared spectrophotometer with a wavelength range between 450 and $4000 \mathrm{~cm}^{-1}$. The sample was prepared by mixing the final product with $\mathrm{KBr}$ powder and pressed to form $\mathrm{KBr}$ pellet. Particle size analysis was carried out by using Malvern Mastersizer $3000^{\mathrm{TM}}$.

\section{RESULTS AND DISCUSSION}

\subsection{Fe precipitates and behavioural pattern}

The Fe precipitates generated were divided into 3 different parts. In first part, precipitation was forced by hydrolysis induced by addition of $\mathrm{NaOH}$; second set was induced by addition of $\mathrm{Ca}(\mathrm{OH})_{2}$; third set the precipitates were obtained after the addition of $\mathrm{H}_{2} \mathrm{O}_{2}$ to oxidize $\mathrm{Fe}^{2+}$ to $\mathrm{Fe}^{3+}$ and increase the medium $\mathrm{E}$ value above $600 \mathrm{mV}$. Precipitates obtained by addition of $\mathrm{NaOH}$ tended to be gelatinous and difficult to filter, whereas precipitates formed by addition of $\mathrm{Ca}(\mathrm{OH})_{2}$ settled readily and were more compact. Interestingly, the precipitates formed by addition of $\mathrm{Ca}(\mathrm{OH})_{2}$ to tailing liquor showed a $\mathrm{E}$ value $<400 \mathrm{mV}$ and was green-black in colour and also settled readily; on exposure to air the precipitate changed to a red-brown colour.

The $\mathrm{H}_{2} \mathrm{O}$ content present in these precipitates were relatively high (Table 2). Images of $\mathrm{NaOH}, \mathrm{Ca}(\mathrm{OH})_{2}$ induced precipitates are shown in Fig. 4 respectively. With the exception of green-black product, the $\mathrm{NaOH}$ and $\mathrm{Ca}(\mathrm{OH})_{2}$ induced precipitates were similar in appearance as were the hematite conversion products. IEM and tailing extract liquor pre and post precipitation ( $\mathrm{pH}, \mathrm{E}$, and total Fe conc.) is presented in Table 3.

Table 2: Water content (\%) of the obtained ferrihydrite precipitates. Samples dried at $100^{\circ} \mathrm{C}$.

\begin{tabular}{|l|c|}
\hline Precipitate source and synthesis method & $\begin{array}{l}\mathrm{H}_{2} \mathrm{O} \text { content of precipitate after } \\
\text { centrifugation or filtration \% w/w } \\
\text { (before hydrothermal conversion) }\end{array}$ \\
\hline IEM + tailing extract liquor $+\mathrm{NaOH}$ to $\mathrm{pH} 3.4$ & 80.1 \\
\hline $\mathrm{IEM}+$ tailing extract liquor $+\mathrm{Ca}(\mathrm{OH})_{2}$ to $\mathrm{pH} 3.4$ & 97.5 \\
\hline $\begin{array}{l}\text { IEM + tailing extract liquor }+\mathrm{H}_{2} \mathrm{O}_{2} \text { until } \mathrm{E}>600 \\
\mathrm{mV} \text { to } \mathrm{pH} 3.4\end{array}$ & 76.0 \\
\hline
\end{tabular}

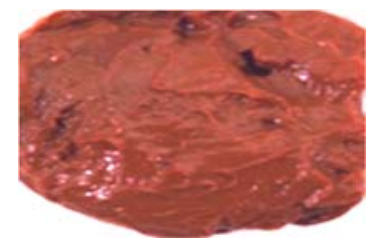

(a)

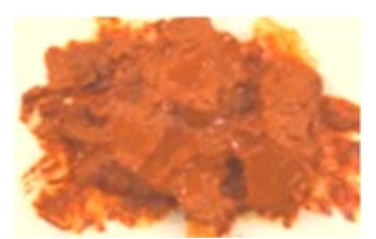

(b)

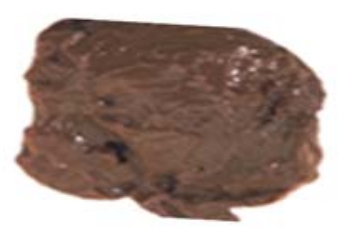

(c)

Figure 4: (a) Precipitate generated by $\mathrm{NaOH}$; (b) $\mathrm{Ca}(\mathrm{OH})_{2}$; (c) $\mathrm{H}_{2} \mathrm{O}_{2}$ induced ferrihydrite precipitate. 
Table 3: IEM and tailing extract liquor pre and post precipitation ( $\mathrm{pH}, \mathrm{E}$, and total Fe conc.).

\begin{tabular}{|l|c|c|c|c|}
\hline \multirow{2}{*}{ Description } & \multicolumn{2}{|c|}{$\mathrm{pH}$} & $\mathrm{E}(\mathrm{mV}) \mathrm{vs} . \mathrm{Ag} / \mathrm{AgCl}$ & {$[\mathrm{Fe}] \mathrm{mg} \mathrm{L}^{-1}$} \\
\cline { 2 - 5 } & Before & After & & \\
\hline IEM culture filtrate & 2.15 & 2.10 & 618 & 3.24 \\
\hline $\begin{array}{l}\text { IEM tailing extract liquor }- \\
\text { post NaOH addition }\end{array}$ & 5.53 & 3.68 & 624 & 0.88 \\
\hline $\begin{array}{l}\text { IEM tailing extract liquor }- \\
\text { post } \mathrm{Ca}(\mathrm{OH})_{2} \text { addition }\end{array}$ & 5.60 & 3.5 & 543 & 1.70 \\
\hline
\end{tabular}

\section{$3.2 \mathrm{Fe}-\mathrm{S}-\mathrm{H}_{2} \mathrm{O} \mathrm{EpH}$ diagram}

The EpH diagram [5] for the $\mathrm{Fe}-\mathrm{S}-\mathrm{H}_{2} \mathrm{O}$ system at $200^{\circ} \mathrm{C}$ and $1.34 \mathrm{MPa}$ was given in Fig. 5. It can be seen that the $\mathrm{Fe}_{2} \mathrm{O}_{3}$ thermodynamic stability predominance area covers a large portion of diagram. The position of the equilibrium lines do not shift significantly with changes in temperature and pressure.

\subsection{FT-IR analysis}

The FTIR spectra plots for both wet and dried spectra are presented in Figs 6 and 7 respectively. Samples were withdrawn at different intervals so as to study the IR spectrum to understand the characteristics features "finger print" region of hematite ranging from 1000 to $200 \mathrm{~cm}^{-1}$. The FTIR spectra in figures show a progressive change in the tailing extract liquor and $\mathrm{NaOH}$ and $\mathrm{Ca}(\mathrm{OH})_{2}$ induced ferrihydrite precipitates to a hematite like solids. It should be noted that these spectra were obtained from wet precipitates hence the adsorption band positions for the hematite phases vary slightly from the literature values, which are

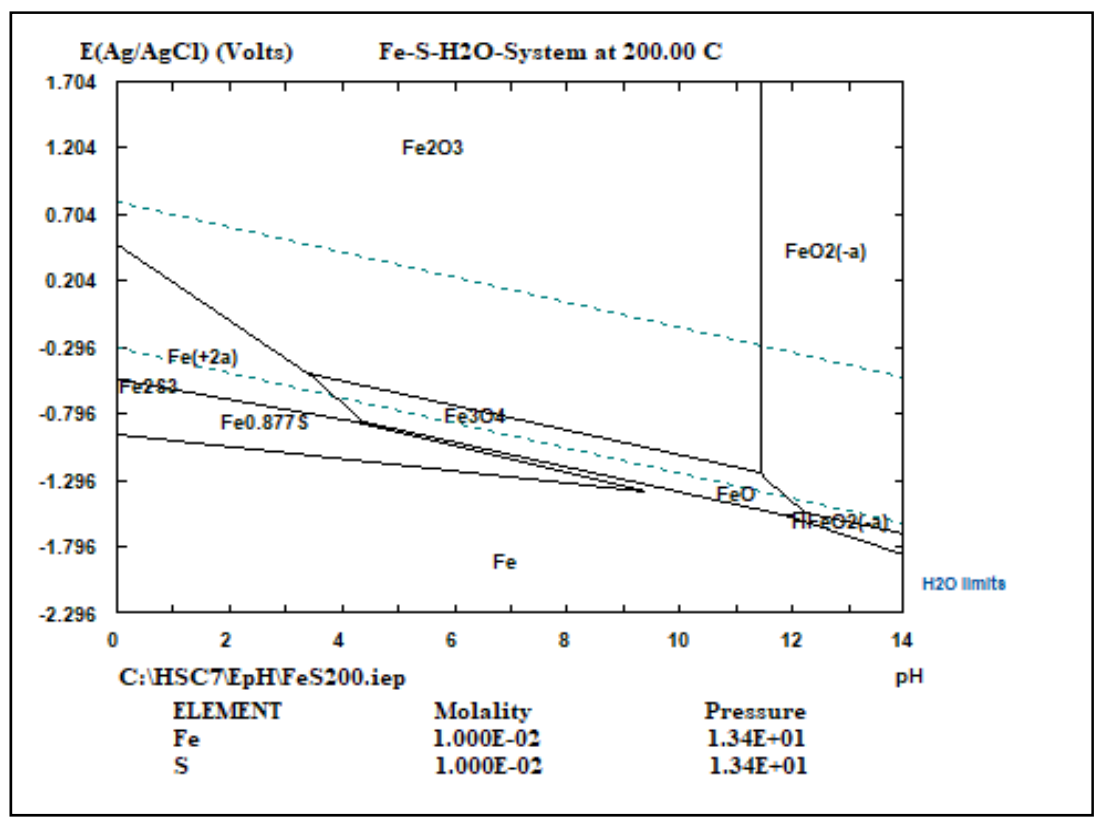

Figure 5: E-pH diagram for the Fe-S-O-H system at $200^{\circ} \mathrm{C}$ and $1.34 \mathrm{MPa}$. 


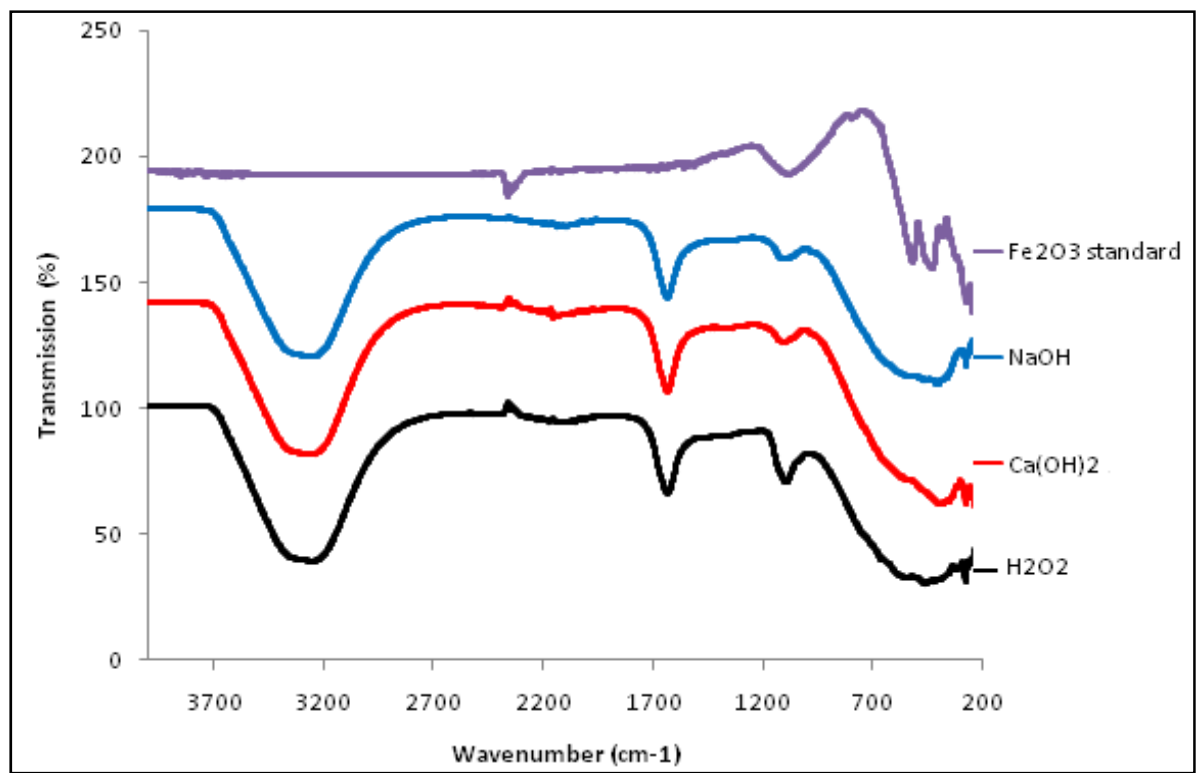

Figure 6: FTIR spectra for "wet" hydrothermal converted products obtained by $\mathrm{NaOH}$, $\mathrm{Ca}(\mathrm{OH})_{2}$ and $\mathrm{H}_{2} \mathrm{O}_{2}$ induced precipitation.

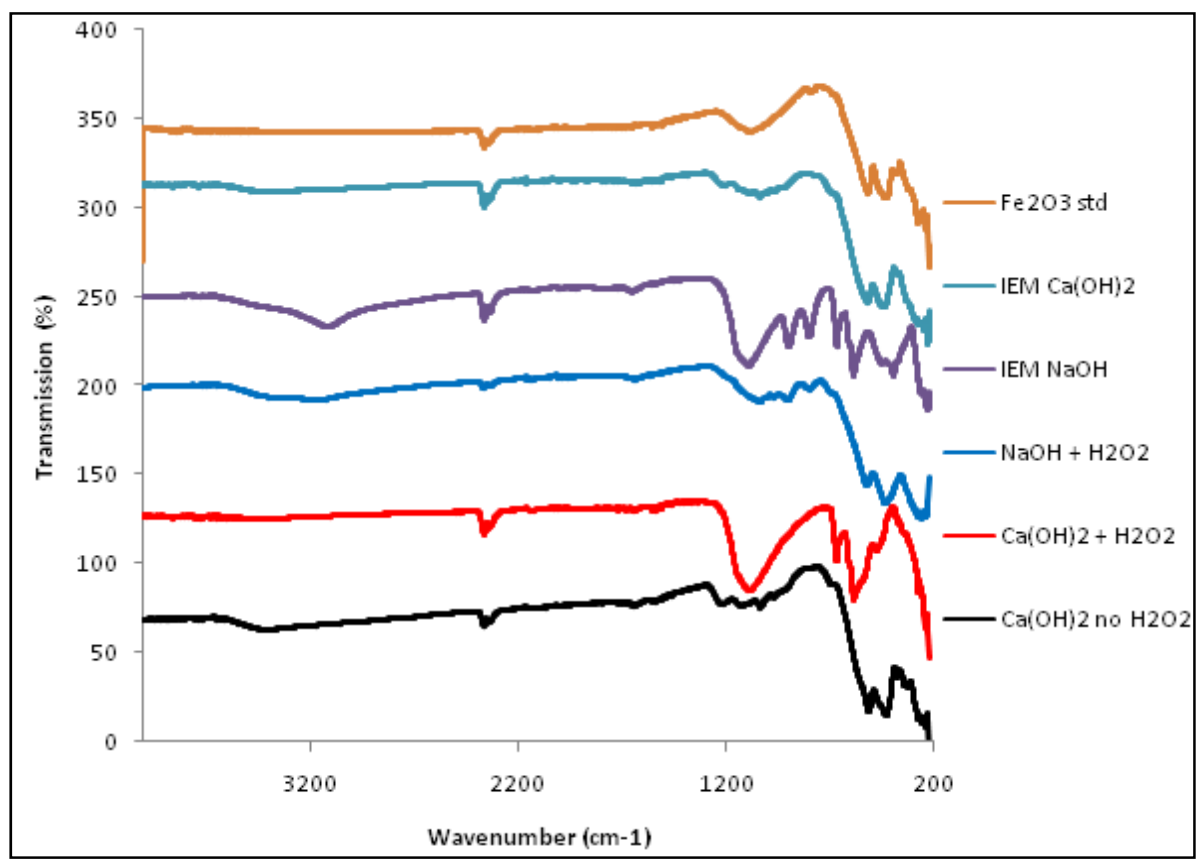

Figure 7: FTIR spectra for dried hydrothermal converted products obtained by $\mathrm{NaOH}$, $\mathrm{Ca}(\mathrm{OH})_{2}$ and $\mathrm{H}_{2} \mathrm{O}_{2}$ induced precipitation. 
quoted for dry samples. Ferrihydrite phases are difficult to dry without inducing a mineral phase change [6]. Some band assignments was done: the broad feature at 3620 to $2600 \mathrm{~cm}^{-1}$ is due to -OH group stretch, the broad peak at 1180 to $980 \mathrm{~cm}^{-1}$ with $\mathrm{OH}-\mathrm{O}$ bend associated with $\alpha, \beta, \gamma-\mathrm{FeOOH}$, and the peak at 1700 to $1520 \mathrm{~cm}^{-1} \mathrm{H}-\mathrm{O}-\mathrm{H}$ bend [7], [8]. The FTIR spectra for the dried hematite like products in $\mathrm{NaOH}$ and $\mathrm{Ca}(\mathrm{OH})_{2}$ matches very close with the $\mathrm{Fe}_{2} \mathrm{O}_{3}$ standard. There is no apparent correlation between the similarity of the spectra with respect to peak intensity and the agent used to initiate precipitation $\left[\mathrm{NaOH}, \mathrm{Ca}(\mathrm{OH})_{2}\right]$, the source of $\mathrm{Fe}$ (IEM, tailing extract liquor) or the oxidation state of the $\mathrm{Fe}\left(\mathrm{Fe}^{3+}, \mathrm{Fe}^{2+}\right)$. This leads to the conclusion that the hydrothermal conversion conditions with respect to solution parameters and temperature are critical for the production of "clean" hematite. The observed IR band values of wet hydrothermal converted product is presented in Table 4 respectively.

\subsection{XRD analysis}

X-ray diffraction spectra for dried samples $\left(50^{\circ} \mathrm{C}\right)$ of the hydrothermal conversion products obtained from IEM and tailing extract is shown in Fig. 8. The as-obtained, ferrihydrite like, precipitates from the IEM and tailing extract liquor tended to give ill-defined and diffuse XRD spectra characteristic of poorly crystalline materials (data not shown), and have not been included in this paper. Several features of the spectra are of interest. Considering IEM origin samples, the two notable features are the intense peak at $2 \theta=25.54$ for $\mathrm{Ca}(\mathrm{OH})_{2}$ precipitated sample and the absence of $2 \theta=26.56$ peak present in the $\mathrm{Fe}_{2} \mathrm{O}_{3}$ standard but not in other IEM origin samples. The XRD spectrum for converted $\mathrm{NaOH}$ precipitate is closer to the literature spectrum for $\alpha-\mathrm{Fe}_{2} \mathrm{O}_{3}$ than the sample used as the hematite standard for this study [6], [9]. The difference may be due to an additional $\mathrm{Fe}_{2} \mathrm{O}_{3}$ phase in the standard or artefact particle morphology. All samples of converted precipitate contained hematite: the origin of the intense peak at $2 \theta=26.56$ for the $\mathrm{Ca}(\mathrm{OH})_{2}$ precipitated sample is uncertain, following the work of [10] a tentative assignment is made for the 310 plane of akaganeite ( $\beta$ $\mathrm{FeOOH})$ according to [11] the latter is a precursor for the dissolution re-precipitation mechanism for $\alpha-\mathrm{Fe}_{2} \mathrm{O}_{3}$ formation. According to literatures, it has been reported that ferrihydrate, a metastable phase, would be generated first in hydrolysis of iron precursor and then transformed to goethite or hematite depending on the $\mathrm{pH}$ of the system [12], [13].

\subsection{SEM-EDX analysis}

The composition and phase purity of the final product generated by $\mathrm{NaOH}$ and $\mathrm{Ca}(\mathrm{OH})_{2}$ induced precipitation was studied by SEM-EDX analysis (Fig. 9). The pigment produced by $\mathrm{NaOH}$ induced precipitations showed cube-shaped $\alpha-\mathrm{Fe}_{2} \mathrm{O}_{3}$ whereas spindle-shaped structure was visualized by $\mathrm{Ca}(\mathrm{OH})_{2}$ induced synthesis. It is known that the morphology and size of $\alpha-\mathrm{Fe}_{2} \mathrm{O}_{3}$ shows strong effects on the widely varying chemical and physical properties. Being more stable and vast applicability these results will certainly help in evaluating its utility and applicability in different fields. Similarly, Peng et al. [14] observed hexagonal

Table 4: Observed IR absorption band values of wet hydrothermal converted product.

\begin{tabular}{|c|c|}
\hline Type of precipitating agent used & $\begin{array}{l}\text { Observed absorption band positions }\left(\mathrm{cm}^{-1}\right) \\
\text { in the finger print region } 200 \text { to } 1000 \mathrm{~cm}^{-1}\end{array}$ \\
\hline $\mathrm{Ca}(\mathrm{OH}) 2$ Induced precipitation & $669,590,517,430$ \\
\hline $\mathrm{NaOH}$ Induced precipitation & $519,432,374$ \\
\hline
\end{tabular}




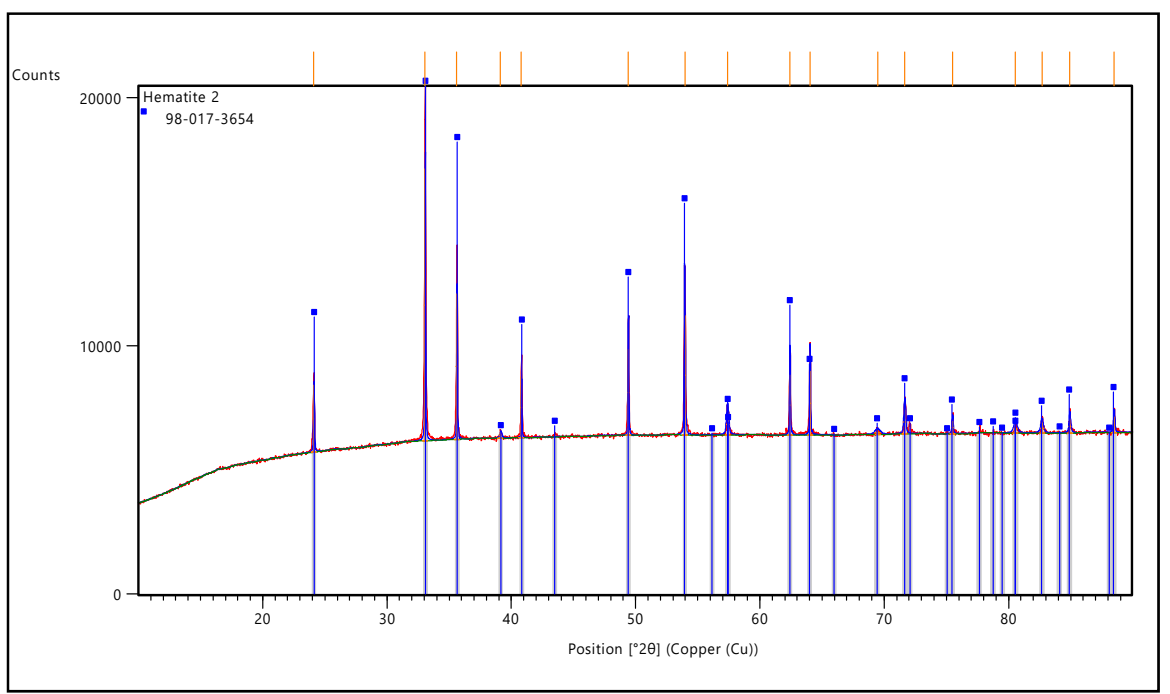

Figure 8: XRD spectra for $\mathrm{Fe}_{2} \mathrm{O}_{3}$ standard and hydrothermal conversion products from conversion of precipitates obtained from tailing extract by addition of $\mathrm{NaOH}$. Assignment of (hkl) crystal planes included. Samples dried at $50^{\circ} \mathrm{C}$.
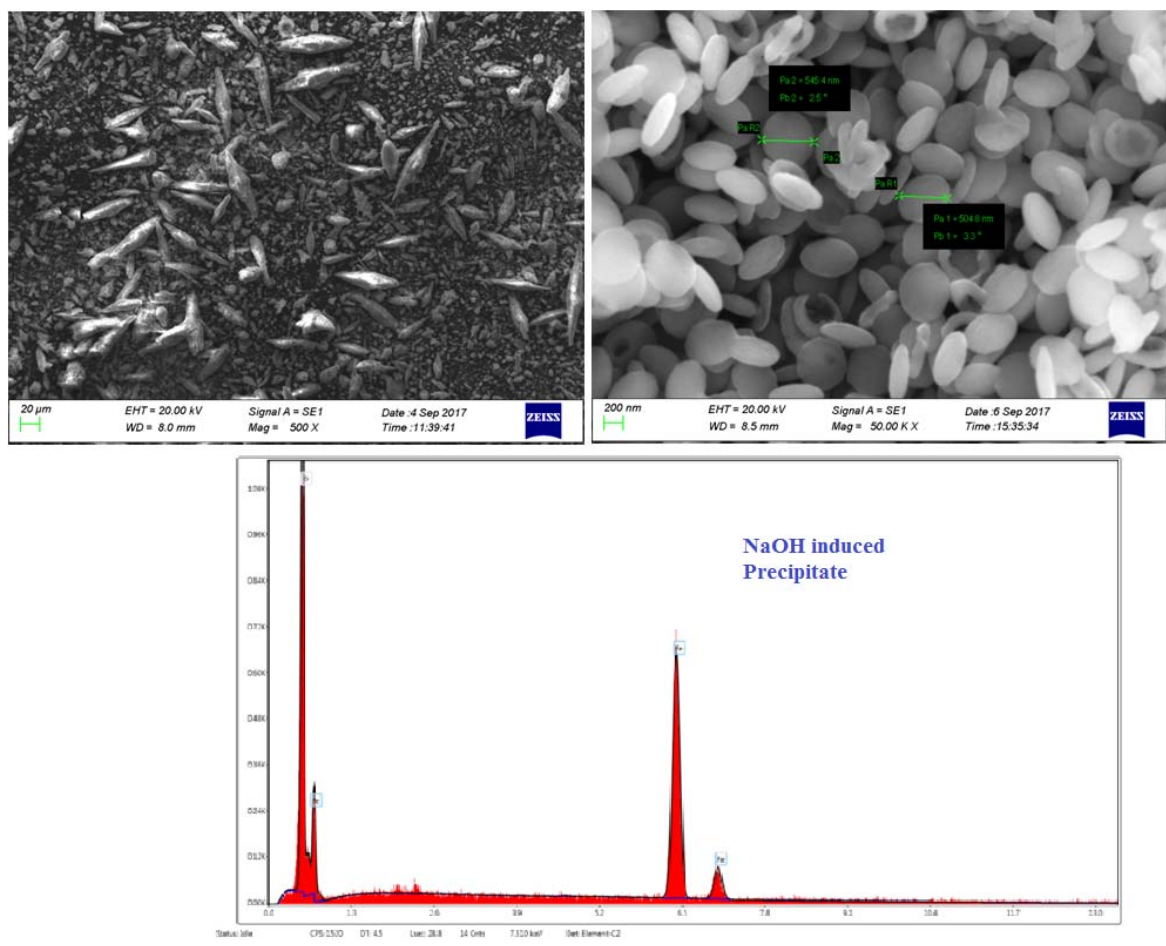

Figure 9: $\quad$ SEM images of $\mathrm{NaOH}$ and $\mathrm{Ca}(\mathrm{OH})_{2}$ induced hydrothermal converted products and EDX analysis of $\mathrm{NaOH}$ induced hydrothermal converted products. 
plates of $\alpha-\mathrm{Fe}_{2} \mathrm{O}_{3}$ [14]. Results suggested that hydrothermal synthesis is one of the most promising method because it offers an effective control over the size and shape of the particles at relatively low temperatures and short reaction times, at the same time provides well-crystallized nanostructures with high degree of homogeneity and definite composition [15], [16].

\section{CONCLUSIONS}

This study has demonstrated the possibility to produce hematite $\left(\alpha-\mathrm{Fe}_{2} \mathrm{O}_{3}\right)$ by hydrothermal techniques from iron ore mine tailing extract liquor. The product of hydrothermal conversion has been confirmed as being $\alpha-\mathrm{Fe}_{2} \mathrm{O}_{3}$ by FTIR and XRD analysis. There is little apparent correlation between the type of medium, the precipitating agent $\left(\mathrm{NaOH}, \mathrm{Ca}(\mathrm{OH})_{2}\right)$ and the quality of the resultant hematite product. However, precipitation by alkaline induced hydrolysis of $\mathrm{Fe}^{3+}$ produces a ferrihydrite like precipitate that is difficult to settle and filter, and also has a high $\mathrm{H}_{2} \mathrm{O}$ content $>80 \% \mathrm{w} / \mathrm{w}$. Therefore, from the above experiment it is confirmed that high content of iron in different wastes generated during metallurgical processes can be solved by producing iron oxide pigments, which can be successfully used in paint, cosmetic, pharmaceutical, dye, chemical industries. Furthermore, it could easily and economically generate additional revenue to develop the infra-structural facilities, the operation and maintenance costs required for full functional operational plant and certainly add value to the economy of these sectors. Looking to the results and potentiality of the product, pilot plant scale has been initiated at NEERI-Delhi Zonal Centre.

\section{ACKNOWLEDGEMENTS}

One of the authors is thankful to SERB-DST, Government of India for the financial support for the project. The authors are also thankful to the Director, NEERI, Nagpur for permitting and providing the facilities to carry out the work.

\section{REFERENCES}

[1] www.mckinsey.com/ /media/McKinsey/Featured Insights/India/Putting India on the growth path/Putting India on the growth path.

[2] Blight, K. \& Ralph, D., Maximum yield and standard enthalpy of growth of ironoxidising bacteria. Hydrometallurgy, 93(1-2), pp. 66-71, 2008.

DOI: 10.1016/j.hydromet.2008.03.002.

[3] Falagán, C., Grail, M.B. \& Johnson, D.B., New approaches for extracting and recovering metals from mine tailings. Minerals Engineering, 106, pp. 71-78, 2017. DOI: 10.1016/j.mineng.2016.10.008.

[4] Morin, D.H.R. \& D'Hugues, P., Bioleaching of a cobalt-containing pyrite in stirred reactors: a case study from laboratory scale to industrial application. Biomining, eds D.E. Rawlings \& D.B. Johnson, Springer-Verlag: Heidelberg, pp. 35-55, 2007.

[5] Pourbaix. M., Atlas of Electrochemical Equilibria in Aqueous Solutions. National Association of Corrosion Engineers, Houston, TX, 1974.

[6] Schwertmann, U. \& Cornell, R., Iron Oxides in the Laboratory: Preparation and Characterisation, 2nd ed., Wiley-VCH, 2000.

[7] Saraswa, I., Vajpei, A., Garg, V., Sharma, V. \& Prakash, N., Characterization and thermal transformation of ferric oxide hydrate gel. Journal of Colloid and Interface Science, 73(2), pp. 373-380, 1980. DOI: 10.1016/0021-9797(80)90083-1.

[8] West, R., CRC Handbook of Chemistry and Physics, ed. R. West, CRC Press: Boca Raton, pp. F190-F198, 1987. 
[9] Yin, C., Manickam, M., Ralph, D., Jiang, Z., Xiec, Z. \& Guoc, H., Hydrothermal synthesis of cubic $\alpha-\mathrm{Fe}_{2} \mathrm{O}_{3}$ microparticles using glycine. Journal of Alloys and Compounds, 509(41), pp. 9821-9825, 2011. DOI: 10.1016/j.jallcom.2011.08.048.

[10] Zic, M., Risti, M. \& Music, S., The effect of temperature on the crystallization of $\alpha-$ $\mathrm{Fe}_{2} \mathrm{O}_{3}$ particles from dense $\beta$-FeOOH suspensions. Materials Chemistry and Physics, 120(1), pp. 160-166, 2010. DOI: 10.1016/j.matchemphys.2009.10.040.

[11] Pu, Z., Cao, M., Yang, J., Huang, K. \& Hu, C., Controlled synthesis and growth mechanism of hematite nanorhombohedra, nanorods and nanocubes. Nanotechnology, 17(3), pp. 799-804, 2006. DOI: 10.1088/0957-4484/17/3/031.

[12] Schwertmann, U., Stanjek, H. \& Becher, H.H., Long-term in vitro transformation of 2-line ferrihydrate to goethite/hematite at 4, 10, 15 and $25^{\circ} \mathrm{C}$. Clay Miner., 39(4), pp. 433-438, 2004. DOI: 10.1180/0009855043940145.

[13] Cudennec, Y. \& Lecerf, A., The transformation of ferrihydrate into goethite or hematite, revisited. Journal of Solid State Chemistry, 179(3), pp. 716-722, 2006. DOI: 10.1016/j.jssc.2005.11.030.

[14] Peng, D., Beysen, S., Li, Q., Sun, Y. \& Yang, L., Hydrothermal synthesis of monodisperse $\alpha-\mathrm{Fe}_{2} \mathrm{O}_{3}$ hexagonal platelets. Particuology, 8(4), pp. 386-389, 2010. DOI: 10.1016/j.partic.2010.05.003.

[15] Byrappa, K. \& Adschiri, T., Hydrothermal technology fornanotechnology. Progress in Crystal Growth and Characterization of Materials, 53, pp. 117-166, 2007.

[16] Almeida, T., Fay, M., Zhu, Y. \& Brown, P., Hydrothermal growth mechanism of a$\mathrm{Fe}_{2} \mathrm{O}_{3}$ nanorods derived by near in situ analysis. Nanoscale, 2(11), pp. 2390-2399, 2010. DOI: 10.1039/c0nr00280a. 